УДК 331.5

O. Nezhyvenko

\title{
INFORMAL EMPLOYMENT IN UKRAINE: 2007 SURVEY APPLICATION
}

Informal employment became a serious challenge for the Ukrainian economy during its adjustment to market conditions. Trends of the number of workers participating in the informal sector have been rising for the last years. The research presents the current state of informal employment in Ukraine. Detailed attention is paid to labour distribution across different population categories. We examine labour market of Ukraine using the data of Ukrainian Longitudinal Monitoring Survey for the year 2007.

Keywords: informal employment, non-observed economy, transition countries, Ukraine.

\section{JEL classification: E26, J46}

\section{Introduction}

Informal employment remains one of the main challenges for Ukraine during its economic transformation period. Transition to a market economy in Ukraine has radically changed the nature of its labour division and employment. Although the Ukrainian labour force is characterised as highly qualified and skilled, the level of labour remuneration is much lower than in developed and developing countries. Ongoing political and economic instability has led to rapid increasing labour mobility and participation of workers in informal employment, where both skilled and unskilled workers have to move in order to find more reliable sources of income. Extensive underground economy, in which workers are "paid under the table" - colloquially described as "salary in an envelope" - are challenges that need to be addressed.

The Ministry of Economic Development and Trade of Ukraine (MEDTU) [15] reports on the size of country's shadow economy for September 2015 at the level of 40 per cent of GDP. Meanwhile, according to one of the latest foreign researches, this number amounted to 44 per cent [9] for the year 2012, which represents Ukraine as one of the transition countries most burdened with informal activities (the estimate of the MEDTU for 2012 is 34 per cent of GDP). Employment in the informal sector in Ukraine has reached $22.9 \%$ of total employment in 2012 for people aged 15-70 [14].

Informal activities tend to make the manners of behaving that have arisen in the informal sector become the moving force also behind measures that are taken in the official economy. Such phenomena have been observed in the last few decades in all the transition countries, and they have been a great obstacle in the way of economic growth [1].

Presence of substantive informal employment hinders economic development of Ukraine and its perception on the international level, being one of the main reasons for weak acceptance of Ukraine as a trustworthy and honourable economic partner. This is reflected in consistently low ranking of the country by the Worldwide Governance Indicators, Doing Business report and other independent foreign cross-country comparisons [11]. The informal sector may be a basis for unregistered workforce, and poses unfair competition for formal firms [13]. In addition, it can become a source for independent changes in the economy (whether procyclical and/or countercyclical) and can affect the direction and strength of country's economic policy [6].

Large informal employment and unbalanced labour market have serious consequences for the official economy. We study the labour market of Ukraine by investigating the factors that determine the choice of the individuals to participate in formal or informal employment considering the characteristics of the individuals. By applying Mincer earnings distribution function to the labour market of Ukraine we determine the factors that influence individuals' wages.

\section{Literature review}

The paper stands at the crossroads of two literatures: the literature on informal employment and the literature on the human capital theory. In general, informal employment is low-paid and does not provide social protection for the worker from the labour legislation of the country. Moreover, if creates 
barriers to the economic inclusion of certain groups of population. We try to explain labour force choices between formal and informal employment in parallel to human capital theory. That is why, Mincer theory has been selected as an instrument to demonstrate earnings divide on the example of the Ukrainian workforce.

Mincer develops human capital theory considering labour as a conglomeration of heterogeneous human beings differing in on-the-job productivity rather than a mix of homogeneous workers in an aggregate production function [5]. In this respect, labour economics shifts attention on the income distribution across workers on the contrary to the distribution of income between labour and capital [8].

In this respect, investing in human capital is the main explanatory variable of income distribution and the occupations that require more training are better remunerated in order to compensate the individuals not only for the direct costs of training, but especially for the postponement of their income period [12]. Mincer makes another interesting point that human capital activities involve not merely the transmission and embodiment of available knowledge in people, but also the production of new knowledge which is the source of innovation and of technical change [5].

What is more relevant for our study is that Mincer human capital theory was later used in the studies of informal employment. Gorodnichenko and Sabirianova Peter [2] used Mincerian earnings functions to analyse returns to schooling in Russia and Ukraine and showed its divergence between two countries. By comparing similar household surveys (Ukrainian Longitudinal Monitoring Survey and Russian Longitudinal Monitoring Survey) to assess wage distribution, the study proves that price effect (labour market returns) is a key factor in the determination of differences in returns to schooling.

Kan and Tansel [3] showed that the workers of the formal sector in Turkey have higher salaries then the ones from informal sector, and self-employed are often less paid than other workers. An interested finding is that the penalty for participating in the informal sector decreases with the level of earnings, so it would be not significant for the upper-tier jobs and may be largely penalized for lower-tier jobs. Hence, the upper-tier jobs would be better remunerated and lower-tier jobs would be heavily penalized.

Pages and Stampini [7] compare labour market divide across formal and informal employment and self-employment in six countries including Ukraine and demonstrate a formal wage premium relative to informal employment in the three Latin American countries, but not in transition economies. The study suggests the existence of barriers to mobility between self-employment and formal employment.

\section{Data}

The main data source for the study is the Ukrainian Longitudinal Monitoring Survey (ULMS) which is considered to be the most complete data source on labour market developments among the countries of the Commonwealth of Independent States. It is a survey of households and individuals designed as a statistically representative sample of the Ukrainian working-age population stratified by age, gender, rural/urban area and regional structure. It presents questionnaire results for about 4000 households and 8500 individuals. This survey, which consists of three waves of panel data (2003, 2004 and 2007) provides an in-depth overview of household life conditions and employment of the individuals. This information enables using this data in order to answer our research questions.

\section{Definition of the informal employment for the Ukrainian labour market}

Informality in the labour market may be defined as "unreported income from the production of legal goods and services, either from monetary or barter transactions, hence all economic activities that would generally be taxable were they reported to the tax authorities" [10]. However, two approaches to define informal employment are the most commonly used: productivity definition and legalistic definition [4].

The productivity definition identifies informal employment by the job characteristics: according to this definition under the category of "informal" fall less-skilled, domestic workers, workers in small firms up to five employees. The legalistic approach defines informal employment by non-compliance with the regulations in terms of labour market rules and social security system. According to the second definition, the informality is characterized by employees and self-employed that are not compliant with the labour market rules, or in another words are not registered.

Current state of informal employment in Ukraine is estimated since 1999 according to the methodology approved by the State Statistics Committee of Ukraine. It was developed on the basis of the Resolution on employment in the informal sector, adopted on the 15th International Conference of Labour Statisticians in 1993. According to this methodology classification, the enterprises participating in 
informal sector must simultaneously meet the following criteria:

- market orientation of economic activity of the enterprise;

- a limited number of employees (up to five people);

- not registered as a business enterprise (uncorporate).

This method is based rather on productivity approach because, according to the national methodology, the informal sector includes all persons who were employed in unregistered enterprises, which are regarded to be households by their size (number of employees). Taking into account national peculiarities of informal labour policy, the number of employees in this sector was expanded in order to include those people who worked on the oral agreement with the employer in the formal sector, without a formal labour agreement (contract), which results in the absence of minimum social guarantees [14]. For our research we will follow legalistic definition because this approach is broader and is well observable based on the available data.
We use data from the ULMS 2007 in order to investigate individuals according to their employment status: formal employee, informal employee, formal self-employed, informal self-employed and unemployed. The individuals are classified into these five categories based on their survey responses. To be regarded as an employee or self-employed, an individual needs to have worked at least one hour during the reference week. From the response to the question whether the employee/self-employed is officially registered or not (on the basis of a written contract) we can identify the status: formal employee (FE) and formal self-employed (FSE) or informal employee (IE) and informal self-employed (ISE). The individual that has not worked during the reference week but was looking for the job is classified as unemployed (U).

Here we present the construction of the variable "Occupation", which was extracted from the individual questionnaire of the 2007 ULMS and it corresponds to the five occupation statuses of the individuals.

Formal employee:

During this last week did you work at least one hour and were paid (or supposed to be paid) for it with money or in-kind or worked unpaid on a farm or in a family enterprise?

Tell me, please, are you officially registered at this job, that is, on a work roster, work agreement, or contract?

Informal employee:

During this last week did you work at least one hour and were paid (or supposed to be paid) for it with money or in-kind or worked unpaid on a farm or in a family enterprise?

Tell me, please, are you officially registered at this job, that is, on a work roster, work agreement, or contract?

Formal self-employed:

During the last week, were you employed in entrepreneurship, business activities, individual work, working in a family enterprise or on a farm, as a freelancer or as a registered entrepreneur? Is [your] activity registered?

Informal self-employed:

During the last week, were you employed in entrepreneurship, business activities, individual work, working in a family enterprise or on a farm, as a freelancer or as a registered entrepreneur? Is [your] activity registered?

Unemployed:

\begin{tabular}{|l|c|}
\hline $\begin{array}{l}\text { During this last week did you work at least one hour and were paid (or supposed to be paid) for } \\
\text { it with money or in-kind or worked unpaid on a farm or in a family enterprise? }\end{array}$ & NO \\
\hline \multicolumn{1}{|c|}{ Or } & NO \\
\hline $\begin{array}{l}\text { During the last week, were you employed in entrepreneurship, business activities, individual } \\
\text { work, working in a family enterprise or on a farm, as a freelancer or as a registered entrepreneur? }\end{array}$ & And \\
\hline \multicolumn{1}{|c|}{$\begin{array}{l}\text { Were you engaged in job seeking or planning to start your own enterprise or farm during the } \\
\text { past four weeks? }\end{array}$} & YES \\
\hline
\end{tabular}


Table 1. Personal background characteristics by occupation category: 2007

\begin{tabular}{|c|c|c|c|c|c|c|}
\hline Variable & $\begin{array}{c}\text { Formal } \\
\text { employee } \\
\text { FE }\end{array}$ & $\begin{array}{c}\text { Informal } \\
\text { employee } \\
\text { IE }\end{array}$ & $\begin{array}{l}\text { Formal self- } \\
\text { employed } \\
\text { FSE }\end{array}$ & $\begin{array}{c}\text { Informal self- } \\
\text { employed } \\
\text { ISE }\end{array}$ & $\begin{array}{l}\text { Unemp-I } \\
\text { oyed } \\
\text { U }\end{array}$ & Total \\
\hline Gender & $0.49(0.5)$ & $\begin{array}{l}0.56 \\
(0.5)\end{array}$ & $\begin{array}{l}0.53 \\
(0.5)\end{array}$ & $\begin{array}{c}0.67 \\
(0.47)\end{array}$ & $\begin{array}{l}0.51 \\
(0.5)\end{array}$ & $\begin{array}{l}0.51 \\
(0.5)\end{array}$ \\
\hline Age & $\begin{array}{l}41.08 \\
(12.3)\end{array}$ & $\begin{array}{l}34.17 \\
(12.3)\end{array}$ & $\begin{array}{l}40.68 \\
(9.24)\end{array}$ & $\begin{array}{c}39.4 \\
(12.4)\end{array}$ & $\begin{array}{l}36.17 \\
(12.5)\end{array}$ & $\begin{array}{c}39.97 \\
(12.41)\end{array}$ \\
\hline Marital status & $\begin{array}{c}0.71 \\
(0.45)\end{array}$ & $\begin{array}{l}0.55 \\
(0.5) \\
\end{array}$ & $\begin{array}{c}0.81 \\
(0.39)\end{array}$ & $\begin{array}{c}0.69 \\
(0.46)\end{array}$ & $\begin{array}{c}0.58 \\
(0.49)\end{array}$ & $\begin{array}{c}0.69 \\
(0.46)\end{array}$ \\
\hline $\begin{array}{l}\text { Size of the } \\
\text { household }\end{array}$ & $\begin{array}{c}2.76 \\
(1.11)\end{array}$ & $\begin{array}{c}2.96 \\
(1.17)\end{array}$ & $\begin{array}{c}2.68 \\
(1.14)\end{array}$ & $\begin{array}{c}2.81 \\
(1.28)\end{array}$ & $\begin{array}{c}2.84 \\
(1.13)\end{array}$ & $\begin{array}{c}2.78 \\
(1.13)\end{array}$ \\
\hline Children & $1.69(0.68)$ & $1.75(0.99)$ & $1.65(0.68)$ & $1.84(0.96)$ & $1.93(0.89)$ & $1.72(0.74)$ \\
\hline $\begin{array}{l}\text { Educational } \\
\text { attainment }\end{array}$ & $\begin{array}{c}2.55 \\
(0.88)\end{array}$ & $\begin{array}{c}2.26 \\
(0.67)\end{array}$ & $\begin{array}{c}2.65 \\
(0.91)\end{array}$ & $\begin{array}{c}2.31 \\
(0.77)\end{array}$ & $\begin{array}{l}2.27 \\
(0.7)\end{array}$ & $\begin{array}{c}2.5 \\
(0.86)\end{array}$ \\
\hline $\begin{array}{l}\text { Education } \\
\text { years }\end{array}$ & $13.45(2.01)$ & $12.48(2.01)$ & 13.78 (1.97) & $12.65(2.26)$ & $12.71(1.83)$ & $13.28(2.04)$ \\
\hline $\begin{array}{l}\text { Place of } \\
\text { residence }\end{array}$ & $\begin{array}{c}0.56 \\
(0.49)\end{array}$ & $\begin{array}{l}0.56 \\
(0.5)\end{array}$ & $\begin{array}{c}0.74 \\
(0.44)\end{array}$ & $\begin{array}{c}0.39 \\
(0.49)\end{array}$ & $\begin{array}{c}0.39 \\
(0.49)\end{array}$ & $\begin{array}{l}0.55 \\
(0.5)\end{array}$ \\
\hline $\begin{array}{l}\text { Working } \\
\text { schedule }\end{array}$ & $0.96(0.19)$ & $0.91(0.28)$ & $0.92(0.27)$ & $0.72(0.45)$ & - & $0.94(0.24)$ \\
\hline $\begin{array}{l}\text { Experience } \\
\text { years }\end{array}$ & $\begin{array}{c}9.03 \\
(9.91)\end{array}$ & $\begin{array}{c}2.08 \\
(3.27)\end{array}$ & $\begin{array}{c}5.77 \\
(4.39)\end{array}$ & $\begin{array}{c}5.58 \\
(6.62)\end{array}$ & $\begin{array}{c}4.45 \\
(4.44)\end{array}$ & $\begin{array}{c}8.03 \\
(9.36)\end{array}$ \\
\hline Multiple jobs & $0.02(0.13)$ & $0.01(0.11)$ & $0.03(0.17)$ & $0.03(0.17)$ & - & $0.02(0.13)$ \\
\hline Income & $\begin{array}{c}915.90 \\
(586.26)\end{array}$ & $\begin{array}{c}798.09 \\
(601.34)\end{array}$ & $\begin{array}{c}1732.55 \\
(2430.92)\end{array}$ & $\begin{array}{c}988.62 \\
(1068.334)\end{array}$ & & $\begin{array}{c}934.56 \\
(767.21)\end{array}$ \\
\hline Number & 2674 & 303 & 160 & 163 & 337 & 3637 \\
\hline
\end{tabular}

Source: own calculations based on the ULMS 2007 wave

We analyze means and standard deviations of the variables chosen for each of the occupation statuses in order to highlight the Ukrainian labour market divide. Table 1 presents averages and standard deviations for the personal background characteristics, by the occupation category: formal employee (FE), informal employee (IE), formal self-employed (FSE), informal self-employed (ISE) and unemployed (U). Table 2 (in Attachment) explains all the variables.

There are less women on average among entrepreneurs, in respect to other workers. They dominate in the category of formal employees, although with a small difference to men. The proportion of unemployed men and women is almost the same. According to the State Statistics Service of Ukraine (2012), men are slightly more engaged in the informal economy than women (22.4 per cent and 22.2 per cent respectively). The age group with the lowest participation is that of the informal employees (average age of 34.17 years), followed by unemployed (36.17 years); formal workers and selfemployed are the oldest (41.08 and 40.68 years respectively). Educational attainment indicates that workers with the highest level (higher learning) are formal self-employed and formal employees. Interestingly, unemployed are not less educated than informal self-employed and employees (2.27 in respect to 2.26 and 2.31).

The variable "education years" displays the same pattern and accounts for an obvious formal/ informal divide. "Experience" is very different considering each category: the highest experience is relevant to formal employees (9.03 years), the lowest - informal employees (2.08 years). Informal employees and informal self-employed have almost the same average number of years of experience. The variable "multiple jobs" does not show a significant difference across categories.

Income level as well as its distribution vary across categories, which proves labour income inequality, being the highest for formal self-employed (UAH $1,732.55$ ) followed by informal self-employed (UAH 988.62) and formal employees (UAH 915.90), and the lowest - for informal employees (UAH 798.09). For the year 2007, minimum salary increased from 
UAH 420 to UAH 460 (UAH 440 on average) and the living wage rose from UAH 492 to UAH 532 (UAH 516 on average), whereas unemployment benefit increased from UAH 292.6 to UAH 313.7.

\section{Conclusions}

We use the data of individuals from Ukrainian Longitudinal Monitoring Survey for the year 2007 in order to investigate the current state of labour market and informal employment in Ukraine by dividing individuals into five employment statuses: formal employee, informal employee, formal self-employed, informal self-employed and unemployed. We show that Ukrainian labour market is quite heterogeneous across the selected five categories, as regards size of each of these categories, income distribution and personal background characteristics of the individuals.

Informal employment constitutes almost a quarter of active labour force, whereas over four out of five being formal workers. Formal labour market participants tend to be older and not single, reside in an urban area, have higher educational attainment, are much more experienced and get higher incomes (especially for the entrepreneurs). These three last characteristics are consistent with human capital theory. Interestingly, unemployed are not less educated than informal workers. We also show that the income for formal self-employed is less stable and has the highest dispersion across all labour market segments.

In our work in progress, we develop the study of informal wages by designing human capital earnings function for the Ukrainian labour market and applying Mincer earnings distribution function in order to investigate the factors that determine the individuals' earnings. Multiple job holding that is present in three out of four employment categories in Ukraine is worth investigating. We enlarge the prospect, studying the current state of wages and distribution in Ukraine and addressing the issue why they are so low in comparison with other transition countries.

\section{References}

1. Bejakovic, P. (2009). Tax Evasion, State Capacity and Trust in Transitional Countries: The Case of Croatia. Drustvena Istrazivanja, 18 (Section 1), 787-805.

2. Gorodnichenko, Y., \& Sabirianova Peter, K. (2005). Returns to Schooling in Russia and Ukraine: a Semiparametric Approach to Cross-country Comparative Analysis. Journal of Comparative Economics, 33 (2), 324-350.

3. Kan, E., \& Tansel, A. (2012). Defining and Measuring Informality in the Turkish Labor Market. 57739, 1-22.

4. Khamis, M. (2009). A Note on Informality in the Labor Market. Journal of International Development, 24 (7), 894-908. Retrieved from http://ftp.iza.org/dp4676.pdf.

5. Mincer, J. (1981). Human Capital and Economic Growth. National Bureau of Economic Research, 803. Retrieved from http:// www.nber.org/papers/w0803.pdf.

6. Ott, K. (2002). The Underground Economy in Croatia. Institute of Public Finance, 12, 1-29.

7. Pages, C. \& Stampini, M. (2009). No Education, No Good Jobs? Evidence on the Relationship between Education and Labor Market Segmentation. Journal of Comparative Economics, 37 (3), 387-401.

8. Polachek, S. W. (2007). Earnings Over the Lifecycle : The Mincer Earnings Function and Its Applications. 3181. Retrieved from http://ftp.iza.org/dp3181.pdf.

9. Schneider, F. (2012). Shadow Economy in Turkey and in Other OECD-Countries: What Do We (Not) Know? Linz: University of Linz. Retrieved from http://www.gep.gov.tr/tmp/BSEC pdf/ Prof. Dr. Friedrich Schneider ShadEc_Turkey2012.pdf.

10. Schneider, F., \& Enste, D. (2000). Shadow Economies: Size, Causes, and Consequences. Journal of Economic Literature, 38 (1), 77-114.

11. Shumska, S., \& Nezhyvenko, O. (2013). Shadow Economy in Ukraine: Methodology and Evaluation. Actual Problems of Economics, 10, 74-83.

12. Teixeira, P. (2006). Jacob Mincer and the Centrality of Human Capital for Contemporary Labour Economics. Retrieved from http://economix.fr/pdf/colloques/2007_HISRECO/5_ Teixeira.pdf.

13. Zimmermann, K. (2006). Causes and Consequences of Labour Immobility. Institute for the Study of Labor. Retrieved from http://vnk.fi/hankkeet/talousneuvosto/tyo-kokoukset/pdf/ Zimmermann___4_September.pdf.

14. Derzhavna sluzhba statystyky Ukrayiny. (2013). Ekonomichna aktyvnist naselennya Ukrayiny 2012 [Economic activity of the population if Ukraine in 2012]. Kyiv.

15. Ministerstvo ekonomichnogo rozvytku i torgivli Ukrayiny. (2016). Tendentsiyi tinyovoyi ekonomiky Ukrayiny, 9 misyatsiv 2015 roku [Trends of the shadow economy of Ukraine, 9 months of 2015]. Kyiv. Retrieved from http://www.me. gov.ua/Documents/List?lang=uk-UA\&id=e384c5a 7 6533-4ab6-b56f-50e5243eb15a\&tag=TendentsiiTinovoiEko nomiki.

Table 2. Description of the variables

Attachment 1

\begin{tabular}{|l|l|}
\hline \multicolumn{1}{|c|}{ Variable } & \multicolumn{1}{c|}{ Description } \\
\hline Gender & $0=$ female; 1 = male \\
\hline Age & Age of the individual in the year 2007 \\
\hline Marital status & $\begin{array}{l}0=\text { Single, widowed, divorced, separated; } \\
1=\text { Registered/non-registered marriage }\end{array}$ \\
\hline $\begin{array}{l}\text { Size of the } \\
\text { household }\end{array}$ & $\begin{array}{l}\text { Number of members of the household: } \\
\text { min }-1, \text { max }-6\end{array}$ \\
\hline
\end{tabular}


Continuation of Attachment 1

\begin{tabular}{|c|c|}
\hline Variable & Description \\
\hline Children & Number of children \\
\hline $\begin{array}{l}\text { Educational } \\
\text { attainment }\end{array}$ & $\begin{array}{l}1 \text { = None or at most primary school; } \\
2=\text { Medium school; } \\
3 \text { = Secondary school; } \\
4 \text { = Higher education; } \\
5 \text { = Vocational or professional training }\end{array}$ \\
\hline Education years & Duration of schooling, continuous in years \\
\hline Place of residence & $\begin{array}{l}0=\text { Rural: village, urban settlement, small town (up to 20,000 inhabitants); } \\
1=\text { Urban: medium town }(20-99,000) \text {, city }(100-499,000) \text {, large city (over } \\
500,000)\end{array}$ \\
\hline $\begin{array}{l}\text { Occupation } \\
\text { (status) }\end{array}$ & $\begin{array}{l}1=\text { formal employee (FE); } \\
2 \text { = informal employee (IE); } \\
3 \text { = formal self-employed (FSE); } \\
4 \text { = informal self-employed (ISE); } \\
5=\text { unemployed (U) }\end{array}$ \\
\hline Working schedule & $\begin{array}{l}0=\text { Always part-time }, \text { sometimes full-time and sometimes part-time; } \\
1=\text { Always full-time }\end{array}$ \\
\hline Experience years & $\begin{array}{l}\text { Duration in years: } \\
\text { Year of survey - year of the first job - years of non-employment }\end{array}$ \\
\hline Multiple jobs & $0=$ no $; 1=$ yes \\
\hline Income & Net monthly salary for employees; net income for self-employed; in UAH \\
\hline
\end{tabular}

\section{Неживенко О. В.}

\section{НЕФОРМАЛЬНА ЗАЙНЯТІСТЬ В УКРАЇНІ НА ОСНОВІ ОПИТУВАННЯ 2007 РОКУ}

Неформальна зайнятість стала великою проблемою для економіки Украӥни в процесі ї̈ адаптаиії до ринкових умов. Динаміка кількості учасників неформального сектора зростає протягом останніх років. Ця стаття є аналізом нинішнього стану неформальної зайнятості Украӥни. Детальну увагу приділено розподілу трудових ресурсів між різними категоріями населення. Ринок праці України досліджено на основі використання статистичних даних опитування Ukrainian Longitudinal Monitoring Survey за 2007 piк.

Ключові слова: неформальна зайнятість, неспостережувана економіка, країни з перехідною економікою, Україна. 